\title{
Penerapan Media Aplikasi Duolingo dalam Meningkatkan Penguasaan Kosakata Bahasa Inggris Siswa SMP Negeri 3 Agrabinta Cianjur
}

\author{
Erna Nursyamsiah \\ SMP Negeri 3 Agrabinta, Kabupaten Cianjur Provinsi Jawa Barat \\ Corresponding Author. Email: rnanursyamsiah@gmail.com
}

\begin{abstract}
This study aims to improve the mastery of English vocabulary for seventh grade students of SMP Negeri 3 Agrabinta through the application of the duolingo application media. This research is a classroom action research conducted in two cycles, with the research subjects being 22 students of class VII. Data collection was carried out through observation, test results of learning, and performance. While the research data analysis technique used qualitative and quantitative descriptive analysis. The results of this study indicate that the application of the duolingo application media can improve vocabulary mastery of seventh grade students of SMP Negeri 3 Agrabinta Cianjur. This can be seen from the percentage of students' completeness in the vocabulary mastery of interpreting words in the second cycle reached $91 \%$ compared to the first cycle, which only reached $55 \%$. The increase was about $36 \%$; in the aspect of reading in the second cycle it reached $100 \%$, compared to that of the first cycle which only reached $82 \%$. The increase obtained was about $18 \%$. And the writing aspect in cycle II reached $95.5 \%$, compared to that during cycle I which only reached $72.7 \%$. The increase obtained was about $23.3 \%$.
\end{abstract}

\begin{abstract}
Abstrak: Penelitian ini bertujuan untuk meningkatkan penguasaan kosakata bahasa Inggris siswa kelas VII SMP Negeri 3 Agrabinta melalui penerapan media aplikasi duolingo. Penelitian ini merupakan penelitian tindakan kelas yang dilaksanakan dalam dua siklus, dengan subjek penelitian adalah siswa kelas VII yang berjumlah 22 orang. Pengumpulan data dilakukan melalui observasi, tes hasil belajar, dan unjuk kerja. Sedangkan teknik analisis data penelitiannya menggunakan analisis deskriptif kualitatif dan kuantitatif. Hasil penelitian ini menunjukkan bahwa penerapan media aplikasi duolingo dapat meningkatkan penguasaan kosakata siswa kelas VII SMP Negeri 3 Agrabinta Cianjur. Hal tersebut dapat dilihat dari persentase ketuntasan siswa dalam penguasaan kosakata aspek mengartikan kata pada siklus II ini mencapai $91 \%$ dibandingkan dengan saat siklus I, yang hanya mencapai 55\%. Peningkatan yang diperoleh sekitar 36\%; pada aspek membaca pada siklus II ini mencapai $100 \%$, dibandingkan dengan saat siklus I yang hanya mencapai $82 \%$. Peningkatan yang diperoleh sekitar $18 \%$. Dan aspek menulis pada siklus II ini mencapai $95,5 \%$, dibandingkan dengan saat siklus I yang hanya menyampai $72,7 \%$. Peningkatan yang diperoleh sekitar $23,3 \%$.
\end{abstract}

\section{Article History}

Received: 16-12-2020

Revised: 02-01-2021

Published: 07-01-2021

\author{
Key Words: \\ Duolingo, Media, \\ Mastery of English \\ Vocabulary.
}

\section{Sejarah Artikel \\ Diterima: 16-12-2020 \\ Direvisi: 02-01-2021 \\ Diterbitkan: 07-01-2021
Kata Kunci:
Media, Duolingo,
Penguasaan Kosakata,
Pembelajaran Bahasa
Inggris.

How to Cite: Nursyamsiah, E. (2021). Penggunaan Media Aplikasi Duolingo Dalam Meningkatkan Penguasaan Kosakata Bahasa Inggris Siswa Kelas VII SMP Negeri 3 Agrabinta Cianjur. Jurnal Paedagogy, 8(1). doi:https://doi.org/10.33394/jp.v8i1.3251

\section{Pendahuluan}

Hal terpenting yang harus dikuasai anak baik di lingkungan keluarga, masyarakat umum maupun di sekolah adalah bahasa. Karena dengan bahasa semua ide, gagasan, anganangan maupun konsep dapat tersalurkan atau tersampaikan. Kadangkala seorang anak yang cerdas dan mempunyai ide-ide cemerlang sekalipun akan mengalami kesusahan dalam mengemukakan ide/pendapatnya hanya karena tidak bisa menggunakan bahasa yang baik. 
Dimana bahasa yang baik ialah bahasa yang digunakan sesuai tempatnya (situasi dan kondisi).

Selain itu, bahasa juga merupakan faktor penunjang keberhasilan seseorang (siswa) dalam mempelajari semua bidang studi. Oleh karena itu, alangkah lebih baiknya apabila pembelajaran bahasa diberikan semenjak dini, supaya anak mampu menggunakan bahasa dengan baik dan benar serta mampu mengkomunikasikan semua yang dirasakannya dengan bahasa yang baik. Juga untuk pencapaian perkembangan kecerdasan berbahasa di masa yang akan datang.

Belajar bahasa Inggris merupakan salah satu pembelajaran bahasa yang sanagat berguna bagi anak di saat ini dan di masa yang akan datang. Pembelajaran bahasa Inggris di sekolah tingkat menengah merupakan kegiatan kurikuler yang diajarkan kepada siswa untuk mengembangkan keterampilan berbahasa. Keterampilan berbahasa Inggris tersebut mencakup keterampilan mendengar, berbicara, menulis dan membaca. Seperti yang dikemukakan oleh Harmer dalam Ningrum (2014), ia mendeskripsikan bahwa bahasa Inggris memiliki empat keterampilan dasar yang meliputi reading, listening, writing dan speaking. Ke empat keterampilan tersebut memang terpisah-pisah satu sama lain, namun memiliki keterkaitan dan bahkan bisa digabung satu sama lainnya. Brown dalam Ningrum (2014) mengatakan bahwa $a$ course that deal with reading skill, then, will also deal with related listening, speaking and writing atau dengan kata lain, pelajaran dengan keterampilan membaca berhubungan juga dengan keterampilan mendengarkan, berbicara dan menulis.

Sebelum mempelajari empat keterampilan tersebut, siswa harus memiliki perbendaharaan kosakata yang memadai. Tarigan (2011) menyatakan bahwa kualitas berbahasa seseorang tegantung pada kualitas kosakata yang dimiliki. Makin kaya kosakata yang dimiliki makin besar pula kemungkinan terampil dalam berbahasa. Pernyataan Tarigan tersebut menjelaskan bahwa peranan kosakata dalam berbahasa sangatlah penting, baik sebagai penyalur gagasan secara tertulis maupun lisan. Hal senadapun diungkapkan oleh Tim ESA dari Black Hill State University (2006) yang menyatakan bahwa: vocabulary or word meaning is one of the keys to comprehension, atau kosakata adalah salah satu kunci dalam pemahaman.

Terdapat anggapan umum bahwa Bahasa Inggris merupakan mata pelajaran sulit sehingga kebanyakan siswa menunjukkan hasil belajar yang kurang memuaskan, dan belum mampu menggunakannya dalam berkomunikasi (Huraiyah, Suryatni, 2020; Achmad, 2018 \& Suherni, 2015). Salah satu masalah yang banyak ditemui dilapangan yakni penguasaan kosakata bahasa inggris yang masih rendah.

Dalam mendefinisikan tentang pengertian kosakata, para ahli bahasa satu sama lain berbeda-beda berdasarkan sudut pandang masing-masing. Namun, mereka sepakat bahwa kosakata merupakan kunci utama yang harus dimiliki seseorang dalam belajar bahasa. Karena semakain kaya perbendaharaan kata seseorang maka semakin besar kemungkinan seseorang untuk terampil berbahasa dan semakin mudah pula ia dalam menyampaikan dan menerima informasi baik secara lisan, tulisan ataupun menggunakan isyarat-isyarat tertentu. Pada dasarnya kosakata dipelajari siswa supaya mereka dapat meningkatkan keterampilan kegiatan menyimak (listening), berbicara (speaking), membaca (reading) dan menulis (writing) dengan baik. Tak terkecuali dalam belajar bahasa Inggris. Oleh karena itu, siswa membutuhkan suatu sistem atau strategi pembelajaran yang tepat untuk menerima, menyimpan serta memunculkan kembali kosakata tersebut setiap saat.

Berdasarkan temuan dilapangan selama mengajar bahasa Inggris di kelas VII SMP Negeri 3 Agrabinta Cianjur, didapatkan beberapa masalah yang menghambat penguasaan 
kosakata bahasa Inggris yang dialami siswa, diantaranya: Rendahnya penguasaaan kosakata yang ditunjukan siswa. Hal ini didasarkan pada hasil ulangan dan post test pra-siklus siswa pada materi family, dari 22 siswa, hanya 2 siswa yang mencapai nilai di atas KKM (63) dan 20 siswa yang mencapai nilai di bawah KKM.

Permasalahan lain yang ditemukan di lapangan adalah keberadaan media pembelajaran seperti LCD untuk pembelajaran interaktif di kelas di setiap kelas, tape atau recorder untuk listening, buku-buku cerita atau teks berbahasa Inggris di perpustakaan, kamus bahasa Inggris yang jumlahnya terbatas dan masih kurang memadai. Padahal keberadaan berbagai media tersebut bisa mempermudah siswa dalam menguasai berbagai kosakata bahasa Inggris. Serta proses pembelajaran yang monoton dimana siswa tidak bisa aktif selama pembelajaran. Guru menyampaikan materi hanya dengan mendikte, siswa mencatat, lalu mengerjakan soal. Hal ini menyebabkan siswa cepat merasa bosan mengikuti proses pembelajaran, siswa memperlihatkan sikap acuh tak acuh terhadap proses pembelajaran, adanya perilaku melamun, mengantuk, dan berbicara dengan teman sewaktu guru menjelaskan di depan kelas.

Pemilihan media yang tepat merupakan salah satu penunjang keberhasilan dalam pembelajaran. Sehingga media memiliki peran yang sangat vital dalam membantu menyampaikan pembelajaran. Media menurut Djamarah (2002) diartikan sebagai apa saja yang bisa dijadikan sebagai penyalur pesan guna mencapai tujuan pengajaran. Dalam arti bahwa media ini digunakan harus sesuai dengan tujuan pembelajaran yang dirumuskan. Hal senada diungkapkan oleh Sanjaya dalam Ningrum (2014) media bukan hanya alat perantara seperti benda, tapi juga manusia sebagai sumber belajar atau kegiatan semacam diskusi, seminar, karyawisata, simulasi dan lainnya yang bisa dikondisikan untuk menambah wawasan, pengetahuan maupun keterampilan pada siswa.

Terkait hal tersebut, penelitian terdahulu mengenai penggunaan media pembelajaran yang dilakukan seperti yang dikemukakan oleh Handayani dalam Jenal Mutaqin (2016), "media pembelajaran akan merangsang anak untuk menyampaikan pikiran, gagasan, ide untuk mengungkapkan perasaannya secara langsung". Penggunaan media akan membuat pembelajaran menjadi lebih menarik, interaktif dan menuntut kemandirian yang tinggi dari siswa. Karena media memiliki kedudukan bukan hanya sebagai alat bantu mengajar, tetapi juga merupakan salah satu cara untuk memotivasi dan berkomunikasi dengan siswa agar lebih efektif (Marfuah dalam Jenal Mutaqin, 2016 \& Muhtasim, 2020).

Pada zaman digital teknologi seperti sekarang ini, salah satu media yang dapat digunakan adalah mobile learning. Mobile learning adalah suatu konsep pembelajaran yang dirancang dengan menggunakan bantuan media pembelajaran yang berbasis mobile seperti smartphone dan internet. Tamimudin dalam Jenal Mutaqin (2016) berpendapat bahwa " $M$ Learning adalah pembelajaran yang unik karena pembelajar dapat mengakses materi pembelajaran, arahan dan aplikasi yang berkaitan dengan pembelajaran, kapan pun dan dimana pun".

Banyak aplikasi berbasis mobile yang diciptakan dengan bertemakan pendidikan, seperti game pendidikan, yang dapat digunakan sebagai media pembelajaran. Salah satunya yang sedang populer sekarang ini adalah Duolingo. Aplikasi Duolingo adalah salah satu aplikasi yang akan membantu kita lebih mahir dan dirasa efektif untuk mengembangkan kemampuan berbahasa asing, juga didukung dengan tersedianya berbagai bahasa didalamnya termasuk Bahasa Inggris. Duolingo sengaja mengusung konsep "bermain sambil belajar" agar terasa lebih menyenangkan dan mudah digunakan oleh semua kalangan umur. Adapun tujuan 
penelitian ini adalah untuk meningkatkan penguasaan kosakata bahasa Inggris melalui penerapan media aplikasi Duolingo pada siswa kelas VII SMP Negeri 3 Agrabinta Cianjur.

\section{Metode Penelitian}

Dalam penelitian ini, metode yang digunakan adalah metode Penelitian Tindakan Kelas (Classroom Action Research). Menurut Madya (2007) penelitian tindakan kelas merupakan intervensi praktik dunia nyata yang ditujukan untuk meningkatkan situasi praktis. Jika ditujukan untuk guru, maka penelitian tindakan kelas ditujukan untuk meningkatkan situasi pembelajaran yang menjadi tanggung jawabnya. Tujuan PTK itu sendiri menurut Sulipan (2008) adalah untuk memecahkan masalah, memperbaiki kondisi, mengembangkan dan meningkatkan mutu pembelajaran. Sementara Suharsimi (2008) mengemukakan bahwa PTK merupakan suatu pencermatan terhadap kegiatan belajar berupa sebuah tindakan, yang sengaja dimunculkan dan terjadi dalam sebuah kelas secara bersama.

Model PTK yang digunakan dalam penelitian ini adalah model spiral dari Kemmis dan Mc. Taggart, yaitu berulang dan berkelanjutan atau berorientasi pada peningkatan dan proses pencapaian hasil belajar. Menurut Suharsimi (2006), model Kemmis dan Mc Taggart memiliki tiga tahap sebagai berikut ini: Planning Acting; dan Reflection. Adapun alurnya dapat digambarkan sebagai berikut ini:

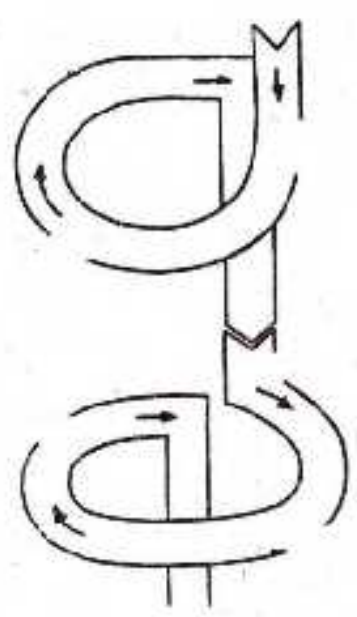

Siklus I

1. Perencanaan

2. Tindakan dan observasi

3. Refleksi

Siklus II

1. Perencanaan

2. Tindakan dan observasi

3. Refleksi

Dst.

\section{Gambar 1. Desain PTK model Kemmis dan Mc Taggart}

Penelitian ini dilaksanakan di SMP Negeri 3 Agrabinta khususnya pada siswa kelas VII A. Waktu penelitian ini dilakukan pada semester ganjil tahun ajaran 2019/2020. Dalam penelitian ini, teknik pengumpulan data yang digunakan antara lain observasi dan tes. Teknik analisis data penelitian ini menggunakan analisis deskriptif kualitatif dan kuantitatif. Hasil observasi dipergunakan untuk mengumpulkan data partisipasi dan keaktifan siswa dalam proses pembelajaran. Teknik observasi data menggunakan rumus teknik proporsi (Sudjana, 1996). Data observasi analisis aktivitas siswa berupa nilai persentasi dengan rumus:

$\mathrm{K}=[\mathrm{A} / \mathrm{N}] \times 100 \%$

$\mathrm{K}=$ Persentase aktivitas siswa dalam pembelajaran

$\mathrm{A}=$ Jumlah nilai aktivitas yang diperoleh siswa

$\mathrm{N}=$ Jumlah total nilaia aktivitas siswa

Untuk membantu dalam mengkategorikan hasil analisis aktivitas siswa, maka digunakan tabel kriteria aktivitas siswa sebagai pemandu analisis data seperti pada tabel berikut ini. 
Tabel 1. Kriteria Aktivitas Siswa

\begin{tabular}{|c|c|}
\hline Persentase Aktivitas siswa & Kriteria \\
\hline $86 \% \leq \mathrm{Pa} \leq 100 \%$ & Sangat Aktif \\
\hline $68 \% \leq \mathrm{Pa} \leq 85 \%$ & Aktif \\
\hline $51 \% \leq \mathrm{Pa} \leq 67 \%$ & Kurang Aktif \\
\hline $\mathrm{Pa}<50 \%$ & Sangat Kurang Aktif \\
\hline
\end{tabular}

Untuk menghitung skor akhir yang diperoleh siswa menggunakan rumus sebagai berikut:

Keterangan:

$$
N=\frac{\text { shor perolehten siswa }}{\text { skor maksimal }} \times 100
$$

$\mathrm{N}=$ Nilai siswa (Darmayanti, 2012)

Untuk menghitung Rata-rata Kelas;

$$
\bar{x}=\frac{\sum X}{N} \quad \begin{aligned}
& \mathrm{X}=\text { Nilai rata-rata kelas } \\
& \begin{array}{l}
\mathrm{X}=\text { Jumlah semua skor siswa } \\
\mathrm{N}=\text { Jumlah siswa }
\end{array}
\end{aligned}
$$

(Suharsimi, 2008)

Untuk menghitung Presentasi Ketuntasan kelas berdasarkan KKM;

$$
P=\frac{F}{N} \times 100 \%
$$

(Darmayanti, 2012)

Menurut BNSP (2012) suatu kelas dinyatakan tuntas apabila dalam kelas tersebut $75 \%$ siswa telah tuntas mencapai nilai KKM.

\section{Hasil Penelitian dan Pembahasan Deskripsi Pra-Siklus}

Pada kegiatan pra-siklus ini, peneliti langsung mengkomunikasikan tentang rancangan pembelajaran yang akan dilakukan di kelas, dengan Kepala Sekolah dan supervisor 2 sebagai teman sejawat di sekolah tempat peneliti mengajar. Selanjutnya peneliti langsung terjun dalam proses pembelajaran Bahasa Inggris yang memang sudah menjadi mata pelajaran pegangan yang diampu di sekolah tersebut setiap harinya. Pada tahap ini, peneliti selain melakukan pembelajaran kepada siswa, juga mengamati proses pembelajaran yang terjadi di dalam kelas pada hari Rabu 18 September 2019 yang berlangsung selama dua jam pelajaran atau 2 x 40 menit.

Dari kegiatan pra-siklus tersebut, peneliti memperoleh nilai hasil ketuntasan belajar penguasaan kosakata bahasa Inggris siswa kelas VII SMP Negeri 3 Agrabinta. Nilai ini diperoleh dari nilai post test yang diselenggarakan setelah proses pembelajaran di kelas. Adapun nilai hasil ketuntasan belajaran penguasaan kosakata bahasa Inggris tersebut adalah

\begin{tabular}{|c|c|c|c|c|c|c|c|c|c|c|c|c|c|c|c|}
\hline \multirow{4}{*}{ Siswa } & \multicolumn{15}{|c|}{ Pra-Siklus } \\
\hline & \multicolumn{5}{|c|}{ Mengartikan } & \multicolumn{5}{|c|}{ Membaca } & \multicolumn{5}{|c|}{ Menulis } \\
\hline & \multicolumn{2}{|c|}{ Ketuntasan } & \multicolumn{2}{|c|}{ Persentase } & \multirow{2}{*}{$\begin{array}{l}\text { Rerata } \\
\text { Nilai } \\
\text { Siswa }\end{array}$} & \multicolumn{2}{|c|}{ Ketuntasan } & \multicolumn{2}{|c|}{ Persentase } & \multirow{2}{*}{$\begin{array}{l}\text { Rerata } \\
\text { Nilai } \\
\text { Siswa }\end{array}$} & \multicolumn{2}{|c|}{ Ketuntasan } & \multicolumn{2}{|c|}{ Persentase } & \multirow{2}{*}{$\begin{array}{l}\text { Rerata } \\
\text { Nilai } \\
\text { Siswa }\end{array}$} \\
\hline & $\mathrm{T}$ & BT & $\mathrm{T}$ & BT & & $\mathrm{T}$ & BT & $\mathrm{T}$ & BT & & $\mathrm{T}$ & BT & $\mathrm{T}$ & BT & \\
\hline 22 & 2 & 20 & $9,1 \%$ & $90,9 \%$ & 45 & 7 & 15 & $31,8 \%$ & $68 \%$ & 61 & 1 & 21 & $4,5 \%$ & $95,5 \%$ & 52 \\
\hline
\end{tabular}
sebagai berikut:

\section{Tabel 2. Ketuntasan Belajar Penguasaan Kosakata Bahasa Inggris Siswa Pra-Siklus}

Dari tabel tersebut di atas, dapat terlihat jelas bahwa penguasaan kosakata bahasa Inggris siswa dari setiap aspeknya sangatlah rendah. Pada aspek keterampilan mengartikan 
kata, dari 22 siswa hanya 2 siswa yang mendapat nilai diatas KKM atau tuntas dengan tingkat ketuntasan sebesar 9,1\% dan 20 siswa lainnya belum tuntas. Sedangkan pada aspek keterampilan membaca siswa yang mendapat nilai di atas KKM sekitar 7 siswa dengan tingkat ketuntasan sebesar $31,8 \%$, sedikit lebih tinggi dibandingkan dengan tingkat ketuntasan dari aspek mengartikan dan menulis yang hanya mencapai 4,5\%.

Jika digambarkan dalam diagram, tingkat ketuntasan belajar penguasaan kosakata bahasa Inggris dari setiap aspeknya selama pra-siklus adalah sebagai berikut:

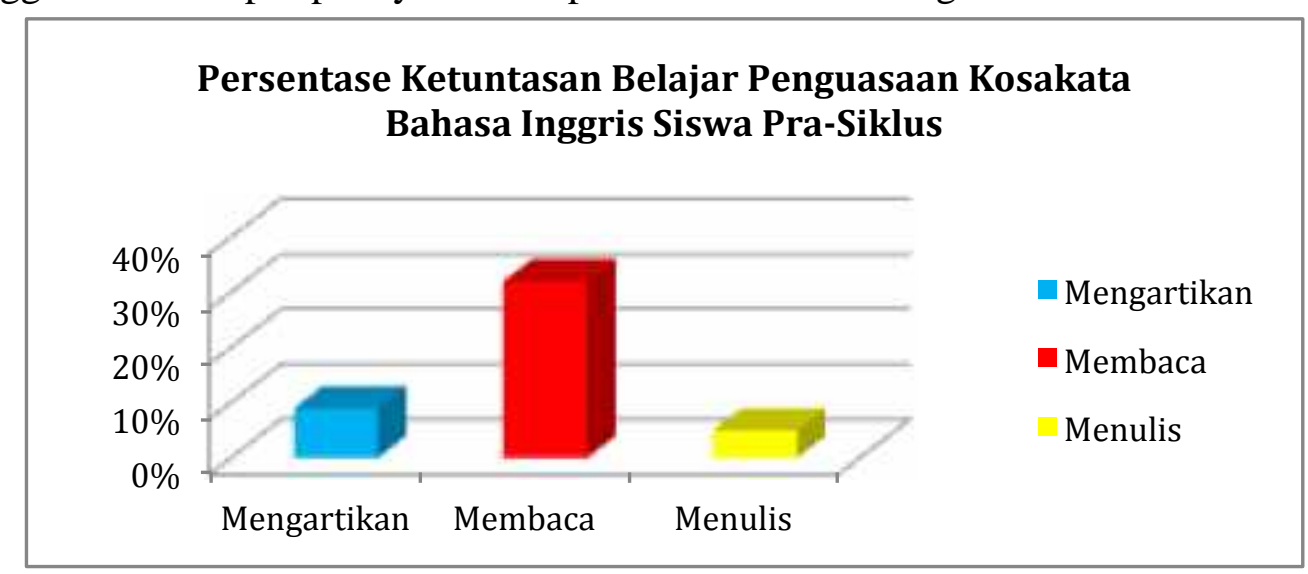

Grafik 1. Ketuntasan Belajar Penguasaan Kosakata Bahasa Inggris

Keadaan inilah yang mendasari peneliti untuk membuat rancangan penelitian selanjutnya.

\section{Deskripsi Siklus I}

Penelitian pada Siklus I dilaksanakan dalam satu kali pertemuan, pertemuan pertama dilaksanakan pada tanggai 25 September 2019 dengan materi "Family". Selama pembelajaran berlangsung, peneliti dibantu oleh teman sejawat dalam mengadakan pengamatan dengan menggunakan lembar observasi yang telah disiapkan.

Berdasarkan hasil tes yang dilaksanakan pada akhir siklus dapat disimpulkan bahwa pada aspek: 1) Mengartikan kata, siswa yang telah tuntas sebanyak 11 siswa dan yang belum tuntas sebanyak 11 siswa, 2) Membaca, siswa yang telah tuntas sebanyak 18 siswa dan yang belum tuntas sebanyak 4 siswa, dan 3) Menulis, siswa yang telah tuntas sebanyak 16 siswa dan yang belum tuntas sebanyak 6 orang. Hal tersebut secara rinci dapat dilihat pada tabel berikut ini:

Tabel 3. Ketuntasan Belajar Penguasaan Kosakata Bahasa Inggris Siswa Siklus I

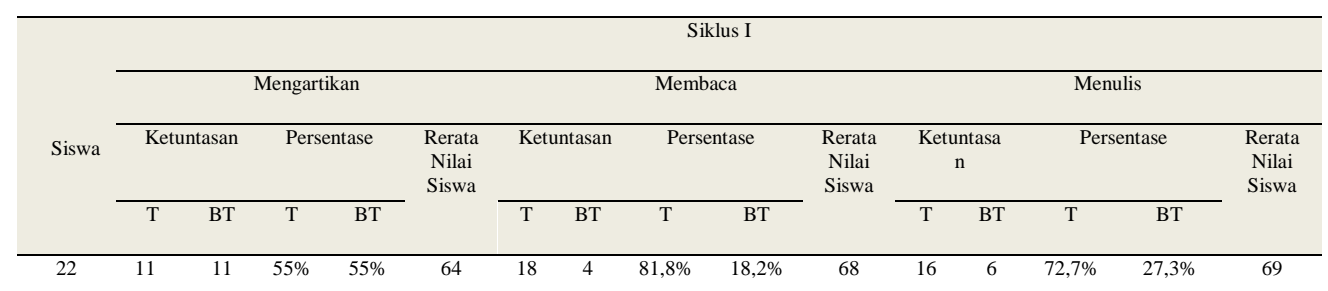

Berdasarkan tabel di atas, dapat disimpulkan bahwa penguasaan kosakata bahasa Inggris siswa mengalami peningkatan dalam segala aspeknya dibandingkan dengan sebelum dilakukannya tindakan. Hal ini dapat dilihat dari jumlah siswa yang telah tuntas pada aspek mengartikan berjumlah 11 siswa dengan tingkat ketuntasan sebesar 55\% dan rata-rata nilai siswa 64. Sedangkan pada aspek membaca jumlah siswa yang telah tuntas mencapai 18 siswa dengan tingkat ketuntasan sebesar 81,8\% dengan rata-rata nilai siswa 68. Begitupun pada aspek menulis jumlah siswa yang telah tuntas mencapai 16 orang dengan tingkat ketuntasan 
$72,7 \%$ dan rata-rata nilai siswa mencapai 69. Jika digambarkan dalam diagram, tingkat ketuntasan belajar penguasaan kosakata bahasa Inggris dari setiap aspeknya selama diberi tindakan pada siklus I adalah sebagai berikut:

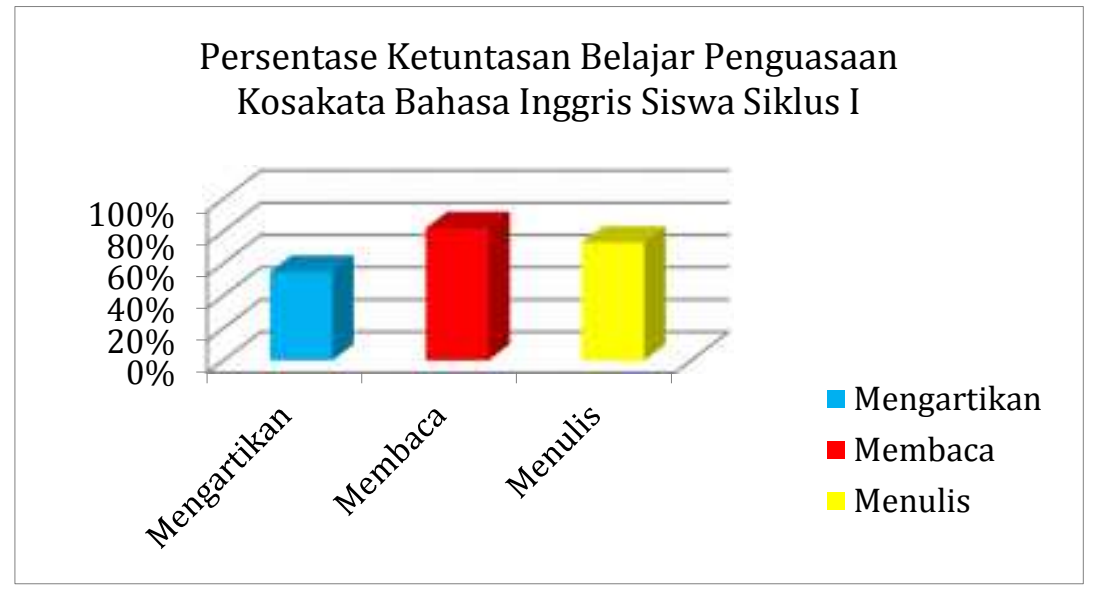

\section{Grafik 2. Ketuntasan Belajar Penguasaan Kosakata Bahasa Inggris}

\section{Deskripsi Siklus II}

Pelaksanaan tindakan siklus II pada dasarnya sama dengan tindakan siklus I, yang membedakan adalah adanya perubahan. Perubahan ini ada karena berasal dari hasil refleksi kelemahan-kelemahan pada tindakan siklus I. Pelaksanaan tindakan siklus ke II ini hanya berlangsung satu kali pertemuan, yaitu pada hari Rabu tanggal 02 Oktober 2019 dengan materi pelajaran yang sama yaitu "family". Berdasarkan hasil tes yang dilaksanakan pada akhir siklus II didapat hasil sebagai berikut :

Tabel 4. Ketuntasan Belajar Penguasaan Kosakata Bahasa Inggris Siswa Siklus II

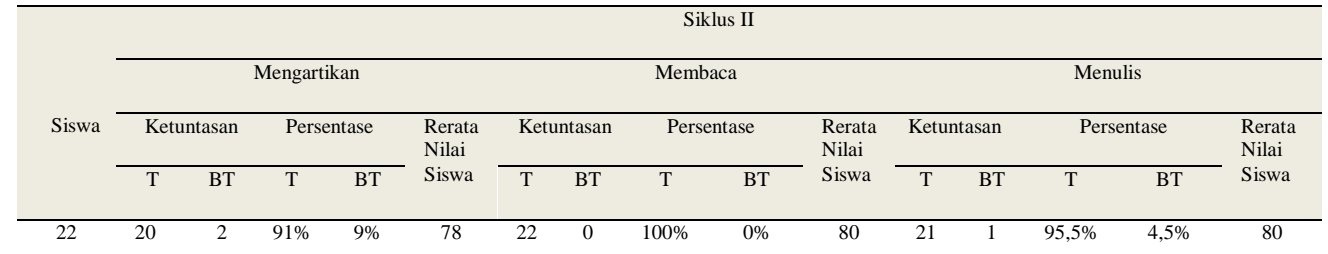

Berdasarkan tabel di atas, dapat disimpulkan bahwa penguasaan kosakata bahasa Inggris siswa mengalami peningkatan dalam segala aspeknya dibandingkan dengan sebelum dilakukannya tindakan dan setelah diberikan tindakan pada siklus I. Hal ini dapat dilihat dari jumlah siswa yang telah tuntas pada aspek mengartikan berjumlah 22 siswa dengan tingkat ketuntasan sebesar $91 \%$ dan rata-rata nilai siswa 78. Sedangkan pada aspek membaca semua siswa telah tuntas dengan tingkat ketuntasan sebesar $100 \%$ dengan rata-rata nilai siswa 80 . Begitupun pada aspek menulis jumlah siswa yang telah tuntas mencapai 21 siswa dengan tingkat ketuntasan 95,5\% dan rata-rata nilai siswa mencapai 80.

Jika digambarkan dalam diagram, tingkat ketuntasan belajar penguasaan kosakata bahasa Inggris dari setiap aspeknya selama pra-siklus adalah sebagai berikut: 


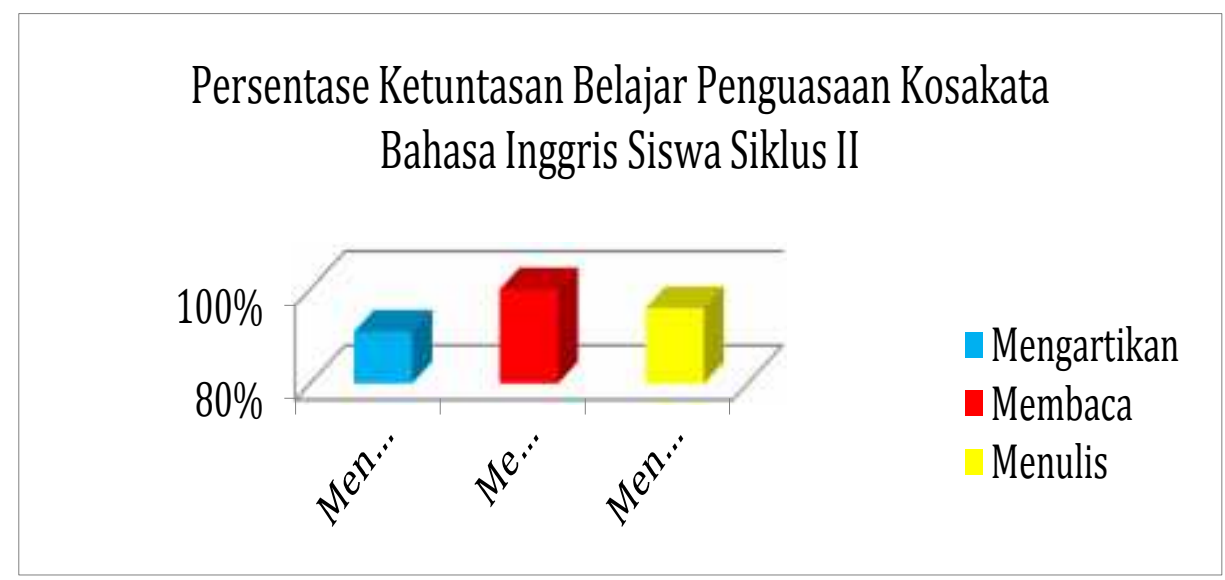

\section{Grafik 3. Ketuntasan Belajar Penguasaan Kosakata Bahasa Inggris} Siswa Siklus II

Berdasarkan pada deskripsi keterampilan berbahasa siswa selama proses pelaksanaan tindakan mulai dari siklus I sampai siklus II sebagaimana telah diuraikan sebelumnya, maka dapat diketahui bahwa penerapan media aplikasi duolingo dalam proses pembelajaran bahasa Inggris dapat meningkatkan penguasaan kosakata siswa. Yakni kosakata aktif produktif atau kosakata yang sering digunakan yakni meliputi indikator mengartikan kata, membaca dan menulis. Peningkatan penguasaan kosakata bahasa Inggris siswa tersebut dapat dibuktikan dengan adanya peningkatan penguasaan kosakata bahasa Inggris serta aktivitas siswa dalam pembelajaran dalam setiap siklusnya.

Dalam aspek mengartikan kata pada siklus II ini, nilai rata-rata siswa adalah 78. Nilai tertinggi adalah 100 yang hanya diraih oleh 1 siswa. Nilai terendah adalah 60, yang diraih oleh 2 siswa. Sementara itu 19 siswa lainnya mendapat nilai antara 70, 80 dan 90. Angka ini cukup membuktikan bahwa keterampilan menulis siswa sudah jauh lebih baik dibanding siklus I.

Jika dipersentasekan, ketuntasan siswa dalam menguasai kosakata aspek mengartikan kata pada siklus II ini yaitu $91 \%$, tentunya mengalami peningkatan yang luar biasa dibandingkan dengan saat siklus I, yang hanya mencapai 55\%. Peningkatan yang diperoleh sekitar 36\%. Untuk lebih jelas melihat peningkatan penguasaan kosakata bahasa Inggris siswa dalam aspek mengartikan kata, dapat kita lihat pada grafik berikut ini:

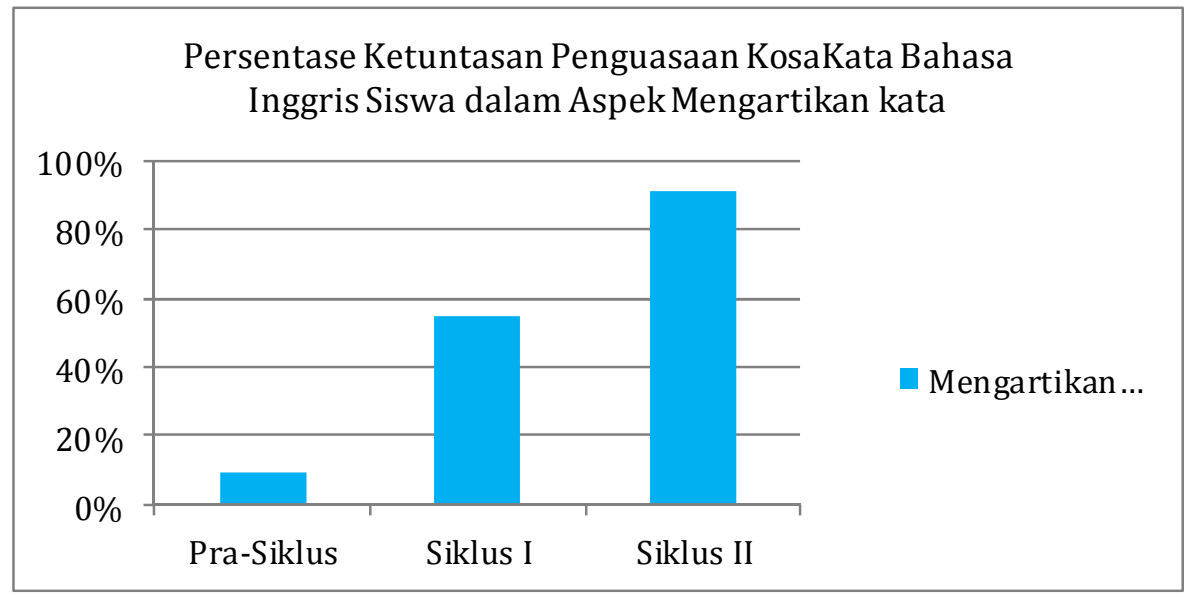

Grafik 4. Persentase Ketuntasan Belajar Penguasaan Kosakata Bahasa Inggris Siswa Aspek Mengartikan Kata 
Sementara itu peningkatan penguasaan kosakata bahasa Inggris yang dicapai siswa dapat kita lihat dari aspek membaca. Pada aspek ini jumlah siswa yang memperoleh nilai paling tinggi yaitu 87 hanya 1 siswa, begitupun yang mendapatkan nilai paling rendah yaitu 74 hanya 1 siswa. Sedangkan sekitar 20 siswa mendapatkan nilai yang bervariasi di atas 74 dan di bawah 87, yang kesemuanya berada di atas KKM yaitu 63. Angka-angka ini cukup membuktikan bahwa keterampilan membaca siswa sudah jauh lebih baik dibanding siklus I yang masih ada siswa yang mendapat nilai dibawah KKM atau belum tuntas.

Jika dipersentasekan, ketuntasan siswa dalam penguasaan kosakata aspek membaca pada siklus II ini mencapai $100 \%$, tentunya mengalami peningkatan yang signifikan dibandingkan dengan saat siklus I, yang hanya mencapai $82 \%$. Peningkatan yang diperoleh sekitar $18 \%$. Hal tersebet dapat kita lihat dengan jelas pada grafik berikut ini:

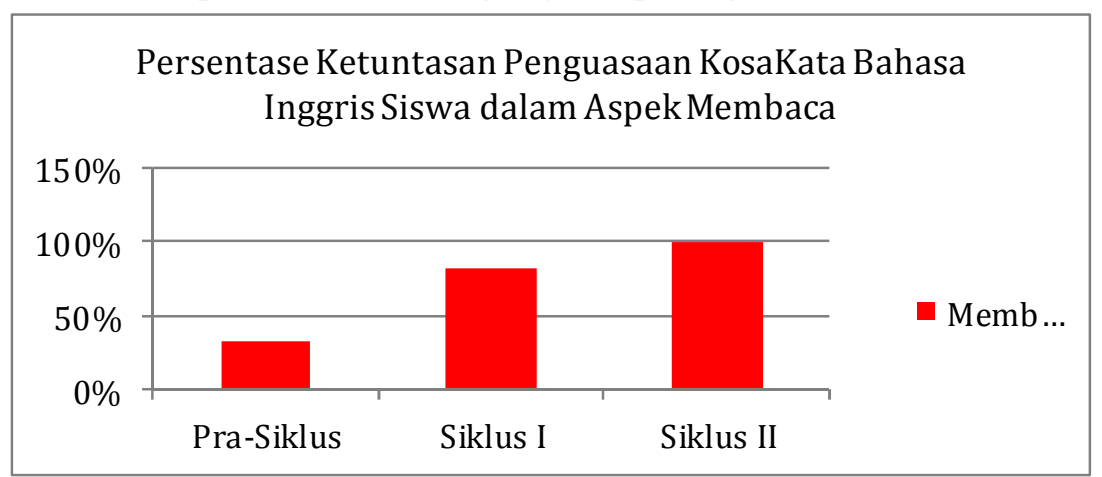

\section{Grafik 5. Persentase Ketuntasan Belajar Penguasaan Kosakata Bahasa Inggris Siswa Aspek Membaca}

Selain itu, peningkatan penguasaan kosakata bahasa Inggris yang dicapai siswa dapat kita lihat dari aspek menulis. Pada aspek ini jumlah siswa yang memperoleh nilai paling tinggi yaitu 90 sebanyak 5 siswa, begitupun yang mendapatkan nilai paling rendah yaitu 60 hanya 1 siswa. Sedangkan sekitar 15 siswa yang lainnya mendapatkan nilai yang bervariasi di antara 70 dan 80, yang kesemuanya berada di atas KKM yaitu 63. Angka-angka ini cukup membuktikan bahwa keterampilan menulis siswa pun sudah jauh lebih baik dibanding siklus I. Jika dipersentasekan, ketuntasan siswa dalam penguasaan kosakata aspek menulis pada siklus II ini mencapai 95,5\%, tentunya mengalami peningkatan yang signifikan dibandingkan dengan saat siklus I, yang hanya menyampai $72,7 \%$. Peningkatan yang diperoleh sekitar $23,3 \%$. Hal tersebut dapat kita lihat dengan jelas pada grafik berikut ini:

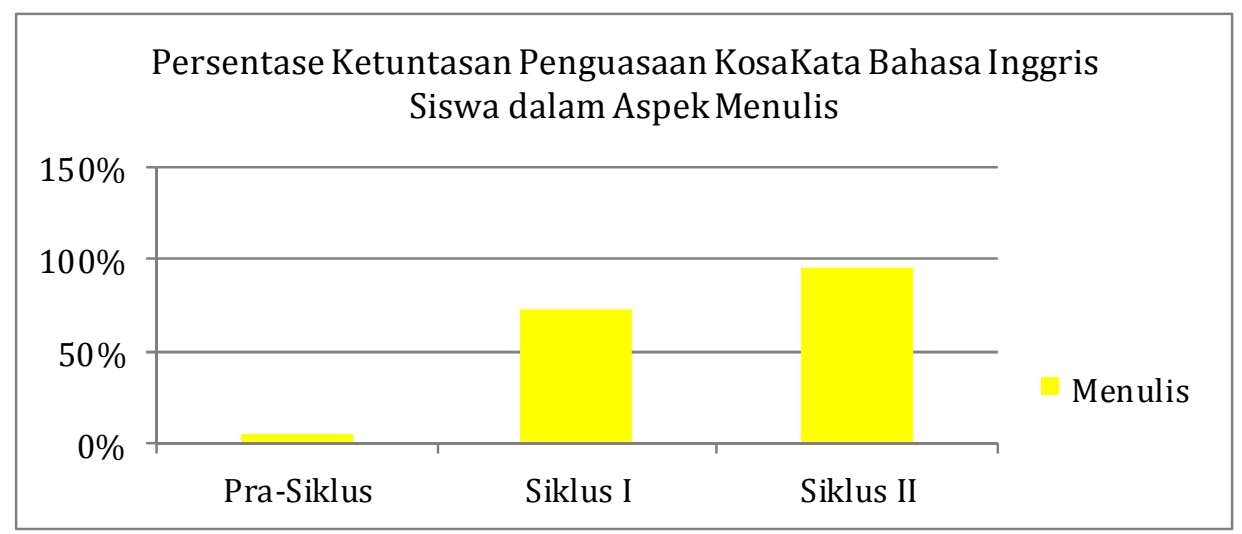

Grafik 6. Persentase Ketuntasan Belajar Penguasaan Kosakata Bahasa Inggris Siswa Aspek Menulis 
Sementara itu, berdasarkan hasil observasi aktivitas siswa pada siklus I dan Siklus II mengalami peningkatan yang sangat positif dimana dari 60,2\% dengan kategori kurang aktif paada siklus I menjadi $92,7 \%$ dengan kategori sangat aktif. Untuk lebih jelasnya dapat dilihat pada tabel berikut ini:

\section{Tabel 5. Presentasi Peningkatan Keaktifan Siswa dalam Pembelajaran Pada Siklus I dan Siklus II}

\begin{tabular}{ccc} 
Item & Siklus I & Siklus II \\
\hline Jumlah Skor & 65 & 99 \\
Presentase Keaktifan & 60,25 & $91,2 \%$
\end{tabular}

\section{Kesimpulan}

Kesimpulan yang diperoleh dari hasil penelitian ini bahwa penerapan media aplikasi Duolingo dapat meningkatkan penguasaan kosakata bahasa Inggris Siswa SMP Negeri 3 Agrabinta Cianjur yang ditandai dengan meningkatnya penguasaan kosakata siswa, baik aspek mengartikan kata, membaca maupun menulis. Dimana sebelum diberi tindakan ratarata nilai siswa sebesar 9,1\% karena hanya 2 orang siswa yang mencapai KKM atau belum tuntas dari 22 (dua puluh dua) siswa. Kemudian setelah diberi tindakan pada siklus I rata-rata nilai siswa meningkat menjadi $77 \%$ dengan siswa yang tuntas sebanyak 17 orang, dan peningkatan juga terjadi pada siklus II, yakni dari hasil tes diperoleh rata-rata nilai siswa sebanyak $100 \%$.

\section{Saran}

Berdasarkan hasil penelitian yang ditemukan, ada beberapa saran yang disampaikan kepada beberapa pihak yang terkait yakni sebagai berikut ini: 1) Bagi Siswa diharapkan bisa mempertahankan atau meningkatkan lagi penguasaan kosakata bahasa Inggris siswa dan keaktifan dalam proses pembelajaran yang sudah meningkat, baik menggunakan media aplikasi duolingo atau aplikasi lainnya; 2) Bagi Guru diharapkan bisa meneruskan proses pembelajaran ini dan menerapkannya dikelas-kelas lain; dan 3) Bagi Pihak Sekolah, penggunaan media aplikasi duolingo diharapkan dapat diteruskan dan dijadikan bahan referensi oleh sekolah kepada guru-guru yang lainnya pada tema kelas yang lain, untuk pengembangan dan peningkatan mutu sekolah.

\section{Daftar Pustaka}

Arief S Sadiman, dkk. (2006). Media Pendidikan Pengertian, Pengembangan, dan Pemanfaatannya. Raja Grafindo. Jakarta.

Achmad, H. (2018). Penggunaan Media Gambar untuk Meningkatkan Kemampuan Menulis Cerita Pendek Bahasa Inggris di SMAN 3 Mataram. Jurnal Kependidikan: Jurnal Hasil Penelitian dan Kajian Kepustakaan di Bidang Pendidikan, Pengajaran dan Pembelajaran, 4(1), 41-47. doi:https://doi.org/10.33394/jk.v4i1.900

Brown, D. (2000). Teaching by Principle: An Interactive Approch to Language Pedagogy. New York: Longman.

Harmer, Jeremy. (2002). The Practice English Language Teaching. Oxford: Longman. http://digilib.unila.ac.id/11549/8/BAB\%20II.pdf. Tinjauan teoritis Media Pembelajaran, Diakses pada tanggal 01 Oktober 2019.

http://sc.syekhnurjati.ac.id/esscamp/risetmhs/BAB214111720038.pdf. Tinjauan Teoritis Hakikat Pembelajaran Bahasa Inggris. Diakses tanggal 01 Oktober 2019. 
https://masdwijanto.files.wordpress.com/2011/03/buku-standar-isi-smp.pdf. Diakses pada tanggal 01 Oktober 2019.

https://eprints.uny.ac.id/15772/1/Peningkatan\%20Penguasaan\%20Kosakata\%20Bahasa\%20I nggris.pdf. Skripsi. Inayatul Fajriyah, 2013. Peningkatan Penguasaan Kosakata Bahasa Inggris Melalui Penggunaan Media Kartu Gambar Pada Siswa Kelas Ii Sd Muhammadiyah Purwodiningratan 2 Yogyakarta. Diakses pada tanggal 01 Oktober 2019.

https://eprints.uny.ac.id/9123/3/bab\%202-08203244001.pdf. Tinjauan Teoritis Penguasaan Kosakata. Diakses pada tanggal 01 Oktober 2019.

Huraiyah, H. (2020). UPAYA PENINGKATAN HASIL BELAJAR BAHASA INGGRIS SISWA DENGAN MODEL PEMBELAJARAN ACTIVE LEARNING. Jurnal Paedagogy, 2(2), 82-86. doi:https://doi.org/10.33394/jp.v2i2.3052

Jenal Mutaqin, 2016. Hubungan Penggunaan Aplikasi Duolingo Sebagai Media Pembelajaran dengan Kepercayaan Diri Berbicara Bahasa Inggris: Universitas Pendidikan Indonesia / repository.upi.edu / perpustakaan.upi.edu. Diakses pada tanggal 01 Oktober 2019.

Jurnal Prima Edukasia. (2014). Peningkatan Penguasaan Kosakata Bahasa Inggris Melalui Media Anagram Dalam Metode Kooperatif Tipe Teams Games Tournament. Hengki Yudha Barnaba, Asruddin Barori Tou. https://eprints.uny.ac.id. Diakses 01 Oktober 2019.

Muhtasim, M. (2020). UPAYA PENERAPAN METODE COOPERATIVE LEARNING TIPE GROUP INVESTIGATION UNTUK MENINGKATKAN HASIL BELAJAR DAN KETERAMPILAN MEMBACA BAHASA INGGRIS SISWA. Jurnal Paedagogy, 2(2), 59-69. doi:https://doi.org/10.33394/jp.v2i2.3049

Ningrum Perwitasari. (2014). Peningkatan Penguasaan Kosakata Bahasa Inggris Materi Family Melalui Lagu Pada Siswa Kelas V Sd N Piyaman II Wonosari. UNY. Yogyakarta. Diakses pada tanggal 01 Oktober 2019.

Suharjo. (2010). Penelitian Tindakan Kelas. Jakarta: PT. Bumi Aksara.

Suharsimi Arikunto. (2008). Dasar-Dasar Evaluasi Pendidikan. Jakarta: Bumi Aksara.

Suherni, S. (2015). Meningkatkan Kemampuan Siswa Menulis Teks Recount Bahasa Inggris Menggunakan Three Phases Techniques pada Kelas VIII.1 (Bilingual) SMP Negeri 7 Mataram. Jurnal Kependidikan: Jurnal Hasil Penelitian dan Kajian Kepustakaan di Bidang Pendidikan, Pengajaran dan Pembelajaran, 1(1). doi:https://doi.org/10.33394/jk.v1i1.403

Sumadi, 2006. Metodologi Penelitian, Jakarta: PT. Raja Grafindo Persada

Suryatni, S. (2020). PEMANFAATAN MEDIA AUDIO UNTUK MENINGKATKAN KETERAMPILAN MENYIMAK CERITA (LISTERNING) BAHASA INGGRIS BAGI SISWA SMAN 2 PRAYA. Jurnal Paedagogy, 4(1), 8-17. doi:https://doi.org/10.33394/jp.v4i1.3018

Suwarsih Madya. (2007). Teori dan Praktik Penelitian Tindakan. Bandung: Alfabeta.

Syaiful Bahri Djamarah, dkk. (2002). Strategi Belajar Mengajar. Jakarta: Rineka Cipta.

Tarigan, H. G (2011). Pengajaran kosakata. Bandung: Angkasa

Widyastuti \& Kusumadewi. (2018). Penggunaan Aplikasi Duolingo Dalam Meningkatkan Kamampuan Kosakata Bahasa Inggris Pada Tenaga Pengajar Bimbingan Belajar Omega Sains Institut. JURNAL ABDIMAS BSI Jurnal Pengabdian Kepada Masyarakat Vol. 1 No. 2 Agustus 2018, Hal. 237-244 E-ISSN : 2614-6711 237 http://ejournal.bsi.ac.id/ejurnal/index.php/abdimas 